\title{
Multiscale fracture analysis along the French chalk coastline for investigating erosion by cliff collapse
}

\author{
Albert Genter $^{1}$, Anne Duperret ${ }^{2}$, Alexandra Martinez $^{2}$, Rory N. Mortimore ${ }^{3}$, \\ Jean-Lou Vila ${ }^{1}$
}

1. BRGM, CDG/ENE, 3 avenue Claude Guillemin, BP 6009, 45060 Orléans Cedex 2, France

2. Laboratoire de Mécanique, Physique et Géosciences, Université du Havre, 25 rue Philippe Lebon, BP 540, 76058 Le Havre Cedex, France

3. Applied Geology Research Unit, University of Brighton, Moulsecoomb, Brighton, BN24GJ, United Kingdom

Corresponding author: a.genter@brgm.fr

Revised version to the Geological Society of London : 20th March 2003

Special issue: "Coastal chalk cliff instability"

Numbers of words of text: 6569

Numbers of references: 18

Numbers of tables: 2

Numbers of figures: 13

Abbreviated title : Fractures and coastal cliff collapse

\begin{abstract}
Coastal cliffs of Upper Normandy and Picardy are eroded by cliff collapses of various sizes. This paper presents a multi-scale analysis of the pre-existing fractures embedded within the Cretaceous chalk. About 20 representative sites equally spaced along the $120-\mathrm{km}$ long coastal section were analyzed and compared to a continuous structural analysis of the coast derived from aerial photographs taken in 1986. Ancient collapses interpreted on the aerial photos were compared to the pre-existing fracture content. Regional faults, pre-1986 collapse location and fracture density are spatially correlated. However, recent collapses observed on the field between 1998 and 2001 did not systematically correlate to the pre-existing fracture occurrence and therefore, there is no clear link between recent collapse and the regional faults.
\end{abstract}


Keywords: Coastal cliff erosion, Fracture network, Cretaceous chalk, Upper Normandy, France

\section{Coastal cliff erosion in Cretaceous chalk}

Erosion of chalk cliffs by collapse is a serious geohazard that induces coastal retreat. In order to understand the cliff collapse mechanism, a multidisciplinary research project co-funded by Europe, called ROCC (Risk Of Cliff Collapse), was carried out between 1999 and 2001. The ROCC project focused on Upper Normandy and Picardy regions in France, from Le Tilleul to Ault (120 km long) and on East-Sussex in UK, from Brighton to Eastbourne (40 km long). Previous studies based on long period analysis suggest that the mean rate of chalk cliff erosion along the Channel coasts varies between 0.2 m/year and 0.3 m/year (May, 1971; Costa, 2000; Dornbursch et al., 2001). Recent field observations in France show that the coastal erosion is spatially and temporally variable and occurs by sudden cliff collapse that could generate significant cliff retreats of 1-10s of metres (Duperret et al., this volume). Cliff instability is governed by a series of parameters of different origins. Pre-existing fractures as well as lithology represent two of those parameters. In the period 1998-2001, a minimum of 55 collapses have been observed along the French chalk coastline and about 10 collapses along the English chalk coastline. For example at Beachy Head in UK, a huge collapse of $150000 \mathrm{~m}^{3}$ occurred in 1999 controlled by vertical pre-existing fractures were involved (Mortimore et al., this volume). At Yport in France, a collapse occurred in 2001 in a fractured cliff characterized by the presence of a series of vertical fractures and of dissolution pipes (Duperret et al., this volume). At Puys in France, a collapse occurred on May 2000 within a very low fractured zone bounded by large-scale fractures (Duperret et al., 2002). From these observations, a preliminary hypothesis was suggested that fractures embedded within the Cretaceous chalk of NW France could influence cliff collapse. The aim of this paper is, therefore, to investigate the relationships that exist between fracture characteristics and cliff collapses. In order to investigate the role of fractures in cliff collapse, we: (1) analysed cliffs forming the French coast at two different scales by combining fracture characterisation (attitude, density, types) on selected sites at field scale, with a continuous analysis of aerial oblique photographs of the coastline; (2) made a complete interpretation of the ancient collapses visible on aerial photographs (location, size) and then compared the results with the cliff fracture content; (3) 
made a comparison between pre-1986 collapses observed on aerial photographs and recent collapses observed in the field in terms of spatial distribution along the French coast. A scar is the fresh rupture surface visible on the vertical coastal cliff after a rock fall event, called here a collapse. Its state of freshness is indicated by the colour differences in the cliff. On the coastal chalk cliff, a fresh scar surface is easily detectable because the chalk colour is white. The scar width is the maximum width of the rupture surface located between the flanks of the cliff collapse. In this paper, a collapse is a generic term that describes a cliff rock fall (Dikau et al., 1996).

The French chalk cliffs of upper Normandy and Picardy regions represent a 3D rock mass with a horizontal distance, about 2000 times greater than the vertical height. The average cliff height is about $60 \mathrm{~m}$ for a coastal strip of about $120-\mathrm{km}$ long. As pre-existing fractures are on scale of metres to $10 \mathrm{~s}$ of metres, it was not possible to investigate them continuously at field scale along $120-\mathrm{km}$. Then, we were obliged to combine geological acquisition based on a series of control areas and a continuous information set represented by the aerial photographs. The choice of the control areas was mainly due to the most accessible valleys, knowing that the cliff height is in average 50 meters in upper Normandy. About 34 zones were visited for geological characterisation (lithology, stratigraphy, structural framework) and collapse data (occurrence, size, run-out, etc...). Furthermore, between St Valéry en Caux and Pourville, that represents about $25 \mathrm{~km}$ length, an exhaustive geological survey has been done along the coastal cliff foot in order to calibrate field analysis and aerial photograph interpreation. Consequently, on the French coast, 2,000 of data (1400 on the cliff, 600 on the beach) were acquired mainly along the coast but also on the beach platform allowing at least a $2 \mathrm{D}$ characterisation of the fracture pattern.

\section{Fracture analysis at field scale}

\section{Fracture typology}

In order to determine the fracture characteristics, a selection of about 20 more or less relatively equally spaced sites were investigated along the French coast (Fig. 1). As the lithology was not uniform along the coast, the analysis was conducted in different lithostratigraphic units. Based on field observations on the cliff face or in the beach platform, a fracture typology was defined. On the cliff, the fracture 
attitude (strike, dip) as well as their vertical extension were measured. The occurrence of shear movements such as slickensides, striation or vertical offsets of flint layers was used to determine the presence of faults. On the beach platform, fracture orientations and more local horizontal fracture traces were collected. Locally, large-scale fractures were observed both on the beach platform and on the cliff. On the cliff, the main fracture types collected in the field were pre-existing fractures (synsedimentary fractures, strata-bound fractures, master-joints, normal faults, joints) and newly created fractures (stress release fractures). Other kinds of structures related to stratification were also recorded including flint levels or marl seams. As the French coast is gently folded, stratification represents a sub-horizontal anisotropy within the cliffs.

(1) Synsedimentary fractures are characterized by $10-\mathrm{mm}$ thick filling made of flint. The presence of flint within the fracture plane is interpreted as a very early genesis for those structures in the chalk basin development. They are small-scale fractures and show a zigzag pattern characterising low anisotropic palaeostress field conditions consistent with the basin creation. They are low dipping fractures. Locally, some vertical striations are visible indicating that they correspond to synsedimentary small-scale normal faults. They are slightly isolated at outcrop scale and they do not constitute wellorganized network. (2) Strata-bound fractures correspond to small-scale normal faults well developed in a given chalk unit (Mortimore, 1990). Those fractures are also interpreted as early synsedimentary fractures. (3) Master-joints are large nearly vertical fractures that cross the whole cliff with an apparent extension of 10 to 100 s metres. They are tiny fractures whose vertical trace is underlined by a Fe-oxide coloration. As they show no indicator of movement, they were defined as master-joints. Vertical dissolution pipes of karstic origin nucleate on vertical master-joints. (4) Normal faults show typical apparent vertical offsets of $\mathrm{cm}$ to metric scale. In some case, vertical slickensides were observed as well as a cataclased damaged zone associated to the major fault plane. They are steeply dipping fractures. Their fracture filling was not investigated systematically but some clay minerals, iron oxides as well as carbonates could be partly sealed the normal fault planes. (5) Joints represent small-scale fractures with no indication of movement. They are isolated structures or organized in more pervasive vertical network embedded within the chalk unit. Their origin is not well constrained. (6) Stress release fractures occur in the vicinity of some valleys, e.g. where the cliff height is rather low, chalk outcrops being highly fractured. Such a network reduces progressively away 
from the valleys. Locally, some newly created vertical fractures parallel to the cliff face were also observed, but they were not investigated systematically. There is no stress release fractures on the beach platform.

\section{Fracture orientation}

About 2,000 fracture orientation measurements were collected on the field (Table 1). The directional fracture set analysis shows a major fracture set, as well as a series of secondary sets. The nearly vertical N110-N130E fracture is the dominant set (Table 2). This set is ubiquitous through the chalk coastline except between Eletot and Senneville sur Fécamp which shows a strata-bound fracture pattern. The secondary fracture sets are characterized by a NO-20E set, a N20-30E set which occurred only at Eletot, and a N40-60E set mainly parallel to the cliff face, which is well represented on the beach platform (Tilleul, St Pierre en Port, Petites Dalles, Bois de Cise) but difficult to observe and then to sample on the cliff face (Fig. 2). The secondary N90-N100E and N160-170E sets have been observed north of Fécamp but are not well represented, whereas the N140-160E set is well represented between Fécamp and Dieppe and north of Criel sur Mer.

In the vicinity of Eletot and Senneville sur Fécamp, the fracture network has an orientation, which is not related to the regional NW-SE trend. The measurements were made in specific chalk units at the bottom of the cliff. Strata-bound fractures consisted of conjugate normal faults, with 10s metre length such as at Senneville sur Fécamp in the New Pit Chalk Formation and at Eletot in the Lower Lewes Chalk Formation where the network was more or less isotropic (Fig. 2). At Quiberville, strata-bound fractures consisted of dual conjugate normal faults with 10 s metre length, giving a pyramidal morphology to the cliff face in the Newhaven Chalk Formation.

From Antifer to Ault, the coastline is mainly oriented NE-SW, whereas the dominating fracture set is oriented N120E with a certain degree of scattering (Table 2). This regional fracture set is made mainly of master-joints and normal faults. It suggests that this NW-SE fracture set could be related to a palaeostress field event oriented NE-SW active from late Cretaceous to early Tertiary times (Vandycke, 1992; Vandycke et Bergerat, 1992). Hibsch et al. (1995) suggest that the normal faulting in the late Cretaceous Chalk deposits is syn-diagenetic faulting related to compaction, inducing a radial 
extensional stress tensor. On the field in Upper-Normandy coastline, the normal faults show a significant N120 E directional anisotropy probably indicative of anisotropic palaeostress tensors. The compaction processes proposed by Hibsch et al. $(1993,1995)$ could have generated the isotropic small-scale normal faults observed at Eletot and Senneville sur Fécamp (Fig. 2) and qualified of stratabound fractures by Mortimore (1993). Along the upper Normandy coastline, as the N120E normal faults are not synsedimentary faults, they are not linked to compaction processes.

A comparison between fracture content on the beach platform and on the cliff face was done in several sites for minimizing the fracture sampling bias. The fracture sampling along the coast is very powerful for collecting fractures intersecting the coast but is not sufficient for characterising what part of the fracture system could be parallel oriented to the coast. On the beach platform, fracture data were collected on profiles which are not parallel to the coast. However, as the fracture system is nearly-vertical, it was rather difficult to measure fracture dips on the platforms. Then, fractures were mainly characterised by their azimuth as only their horizontal traces are visible. Moreover, along the coast, all the beach platforms are not easily accessible due to beach sediment deposits (sand, shingle). Then, only 11 sites were investigated on the beach platform for evaluating the fracture content. About 600 fractures were collected on these different horizontal accessible surfaces (Table 2). On the vertical cliff faces, about 1400 fractures were collected in 34 different sites. In order to minimize the sampling bias along the coast, some field works were focused on the best outcropping cliff and beach platform. For example, in Bois de Cise, 100 and 123 fractures were collected on the cliff and the platform respectively (Fig. 2). On the beach platform, the fracture system is mainly organized around two fracture sets : (1) a dominating fracture set oriented NW-SE and (2) a secondary fracture set oriented NE-SW. On the cliff face, the fracture system is more scattered around the principal fracture set oriented NW-SE. A secondary fracture set is oriented NNE-SSW. Based on this analysis, we can concluded that the main fracture system is mainly oblique to the coast and is well revealed on both the cliff and the beach platform. Parallel fractures to the coast occur but they do not correspond to a principal fracture set (Table 2).

The fracture pattern embedded within the Cretaceous chalk of upper Normandy and Picardy is characterized by (1) a dominant NW-SE vertical network of master joints and normal faults, (2) the 
presence of two secondary fracture sets oriented NE-SW and NNW-SSE, better sampled on the beach platform (Table 2) and, (3), locally, the presence of relatively isotropic conjugate small-scale normal faults developed in particular chalk units and called strata-bound fractures. The fracture network encountered within the Cretaceous chalk of Normandy has a pattern made of at least twosecant fracture sets (Fig. 3). The interpretation of aerial photos described below is used to determine the fracture density continuously along the coast.

\section{Fracture analysis on aerial photography}

A series of oblique black and white aerial photographs of the coastline taken in 1986 was available at an approximate scale of 1:5,000 for an exhaustive interpretation of the cliff and its beach platform. Before carrying out the photo interpretation, some corrections were applied for the oblique nature of the dataset and the problem related to the photograph shot. During the data acquisition, the horizontal distance between the aeroplane and the cliff face was not constant. As a result, some distortions occurred and the photos were mainly interpreted in their central part, for minimising the sampling bias.

In order to generalize the local structural information collected on the selected sites, about 450 photos were interpreted (Vila, 2000). An interpretative methodology was thus outlined on the best quality photographs in which several features (collapses, fractures, dissolution pipes, shingle platform, cliff limits, etc...) were analysed continuously from Antifer to Ault (Vila, 2000). As the aim was to provide data for a GIS application, the following relevant layers of information derived from the photo interpretation were integrated: (1) the fracture content visible on the cliff face, which corresponds to the fractures orthogonal to the cliff face; (2) the fracture content visible on the beach platform, which mainly corresponds to the fractures parallel to the cliff and (3) the collapse characteristics (size, location).

An example of a raw aerial photograph is presented on Figure 4. It shows the Bois de Cise area in the northern part of the French coastline. The vertical chalk cliff is very fractured and shows several parallel large-scale fractures dipping north corresponding mainly to normal faults and master-joints that cut the cliff face. At the bottom of some fractures, there are some triangle-shaped caves. At the 
cliff bottom, several collapses are located either in relatively low fractured zones or in highly fractured zones. They were qualified as ancient collapses or pre-1986 collapses because the aerial photographs were taken more than 15 years ago. It was not possible to clearly identify what kind of cliff collapse was involved even though a large diversity of failure collapse types is suspected in chalk cliff on both sides of the Channel (Duperret et al., this volume, Mortimore et al., this volume). For each observed ancient collapse, its horizontal extension was measured parallel to the cliff providing a collapsed width. Those collapses visible on the aerial photo did not all occur in 1986 but correspond to the cumulative erosional activity of several years of cliff collapse. Actually, it is well known that some large scale collapses are relatively old and are still visible on the beach platform such as the "Chien neuf' collapse located close to Senneville sur Fécamp that occurred more than 70 years ago (Rodet, 1992). On the beach platform some fractures parallel or orthogonal to the cliff face are also visible as well as some marine gullies. Even though the sampling bias related to the oblique photos occurred, the cliffs appear always more fractured than the beach platforms. This observation was also made during the field analysis. The pre-existing fractures are more visible on the cliff because the fracture fillings which are generally dark-coloured, were not eroded. On the beach platform, sea erosion takes place and the pre-existing fractures become more difficult to detect.

\section{Calibration of aerial photo interpretation}

As the aerial photographs are continuous, their calibration was necessary in order to get the best structural identification of the interpreted photo fractures and to determine the actual scale of the photographs. The structural knowledge of the field scale through the 20 equally spaced selected studied sites equally spaced was helpful in providing a better understanding of the aerial photo interpretation.

A continuous section between Pourville to St Valéry en Caux was investigated at field scale and compared with the cliff photo interpretation (Fig. 5). In this section of about $25 \mathrm{~km}$ long, all the preexisting fractures visible in the field were classified, measured and located (Fig. 6). Three main types of fractures were observed in the field: (1) Normal faults characterized by a N120E orientation. Secondary fracture sets oriented N-S and E-W were present preferentially between Quiberville and 
St Aubin where they formed conjugate networks. In terms of size, they were mainly cross-cliff fractures but the N-S and E-W fault sets were small-scale normal faults. (2) Master-joints, characterized by a dominant N110-120E orientation, were large-scale steeply dipping fractures. (3) Synsedimentary faults, which are quite isolated, showed oblique dip values ranging between 50 and $70^{\circ}$ and $\mathrm{E}-\mathrm{W}$ to NW-SE orientations. These last small-scale to medium scale fractures were mainly filled by black flint.

As the aerial photos are oblique, it was not possible to obtain from them quantitative information about fracture orientations. However, an apparent dip value can be determined as well as their vertical extension. The lack of information about fracture orientation from the photo interpretation is not penalising because the fracture analyses carried out in the 20 different sites and continuously between Pourville and St Valéry en Caux, showed a very consistent fracture orientation around the N120E direction (Table 1). It means that the oblique photos of the coastline highlight the dominating fracture set with steeply dipping planes. The vertical extension of the fractures visible on the cliff face can also be obtained from the photographs which is especially useful for detecting the largest fractures.

Between Pourville and St Valéry en Caux, the detailed comparison between the field data and the aerial photo interpretation indicates three main calibrating guidelines applicable at the scale of the French coastline. (1) The fracture density, e.g. the total number of fractures visible on a given horizontal distance, observed in the field or interpreted on the aerial photo shows a value in the same range of magnitude. In this case, the main fracture types visible in the field are large-scale fractures made of normal faults or master-joints which are, therefore, correctly detectable on the photographs due to their large vertical extension. (2) The fracture density deduced from aerial photo interpretation is higher than those measured on the field. The over-estimation of the aerial photo fractures is due to the presence of small-scale to medium-scale structures that are not well constrained in terms of origin. For example, a lot of joints not well defined (induced fractures or stress release fractures) or some vertical morphological structures could be visible in some altered cliffs around Pourville. In some aerial photos, a given large-scale fracture is divided into several apparent smaller segments due to the obliquity of the photo shot leading to a slight over-estimation of the fracture density. In other places, a not well-defined vertical network of pervasively distributed joints may be revealed on aerial photos. The field evaluation has shown that these networks do not really correspond to relevant pre-existing 
fractures. Such structures lead to an over-estimation of the fracture content on aerial photos. (3) The fracture density deduced from aerial photo interpretation is lower than those measured on the field. In this case, inclined synsedimentary fractures filled with flint as well as some small-scale normal faults oriented N-S and E-W, were not systematically detectable on the aerial photos. There are about $15 \%$ of the field fractures which are not visible on the photos. They correspond generally to tiny synsedimentary fractures with various orientation and normal faults, parallel to the cliff, and consequently difficult to characterize even with high resolution photos. Finally, as most of the fractures show a vertical extension higher or equal to the cliff height, the field fractures were easily detectable on the photo.

Two fracture sizes are visible on the cliffs that mainly correspond to two main groups of fracture types: the small-scale fractures (joints, synsedimentary fractures, stress release fractures, induced fractures) and the large-scale fractures (normal faults, master-joints). Generally, the small-scale fractures are more poorly sampled than the large-scale fractures, on aerial photos. Therefore, based on the aerial photograph analysis, two different fracture densities were calculated: the whole fracture density that mixes all the fractures types, called Total Fracture Type (TFT) and the large-scale fracture density that takes into account the large-scale fractures only, called Major Fracture Type (MFT).

The second goal of the calibration procedure was to determine the actual scale of the oblique aerial photographs knowing that there were some distortions on the raw aerial photos. In the field, between Pourville and St Valéry en Caux, measurements were made to provide some typical beachmarks. The horizontal distance between similar features identified both in the field and on the aerial photographs was measured allowing checking the actual photo-scale, which is 1:4,900. This field scale calibrated value was very close to the initial scale value and allowed us to derive real fracture densities from aerial photographs.

\section{Fracture data analysis on aerial photographs}

For building the geohazard map of the coastline, it was necessary to divide the coast into adjacent sectors having a given state of fracturing. Therefore, based on aerial photo fracture evaluation of the 
cliff, the coast has been delineated into a series of sectors having a homogeneous fracture content with a low, average, or high fracture density (Fig. 7). Between Ault and Antifer, 63 sections with different length have been determined. In each section, the total number of fractures, the section length as well as the whole linear fracture density were calculated, knowing that the horizontal scale was calibrated in the field. The sector with the highest density of fractures was Puys with 0.172 fract. $/ \mathrm{m}$. The sector with the lowest density of fractures was close to Penly with 0.011 fract. $/ \mathrm{m}$. Several sectors showed a fracture density close to zero because they corresponded to areas with very low cliff height (perched valleys) or valleys (town, harbour). The average fracture density along the coast was $0.074 \mathrm{fract} . / \mathrm{m}$. As we were looking for some relationships between fracture content and cliff collapse, the fracture data were expressed as fracture spacings. The lower the fracture density, the higher the spacing values. For example, a fracture density of 0.02 fract./m, means that the minimum horizontal distance between 2 consecutive fractures, i.e. the fracture spacing calculated as the inverse of the fracture density, is $50 \mathrm{~m}$.

Between Antifer and Ault, the map of the Total Fracture Types (TFT) shows some sectors with low fracture spacing, ranging from 5 to $10 \mathrm{~m}$, which alternate with sectors with high fracture spacing, ranging from 50 to $100 \mathrm{~m}$. 90\% of the fracture spacing range between 5 and $25 \mathrm{~m}$, the average value being $13 \mathrm{~m}$. At regional scale, the most fractured sectors match with large scale faults such as the Fécamp-Lillebonne fault (at Fécamp), the Bray Fault (at Dieppe) and the Eu Fault (at Mers les Bains) (Fig. 8). The length of the highly fractured coastal sections extends of a few kilometres on each side of the regional faults, such as observed between Yport and St Martin aux Buneaux. The coastal sections located south of Yport, as well as between St Martin aux Buneaux and Cap d'Ailly, and Penly and Criel sur Mer, are characterized by a low fracture content. These sections are both far away but relatively equally spaced from the major regional faults.

The map of the Major Fracture Types (MFT) which corresponds to the master-joints and the normal faults is herein compared to the TFT strip (Fig. 8). The fracture spacing varies between 7 and $182 \mathrm{~m}$, the average value being $30 \mathrm{~m}$. Due to the lower fracture content, the MFT strip systematically shows higher spacing values than the TFT strip, except in the north between Criel sur Mer and Ault. In this northern area characterized by the occurrence of the Eu fault, the fracture content is very high and 
similar for both MFT and TFT and corresponds mainly to large-scale normal faults oriented N120E checked in the field. The MFT strip shows moderate fracture content around the Bray fault. Near the Fécamp-Lillebonne fault, the MFT strip reveals very low fracture content as well as between St Martin aux Buneaux and Veules-les-Roses.

From the MFT strip, here appear to be two main domains of fracture content. Northward from the Bray fault, the high fracture density due to normal faults is indicative of a high tectonic paleo-activity, whereas southward from the Bray fault, the fracture density is lower, suggesting that normal faulting is not so well developed. At larger scale, the tectonic activity of the Bray and Eu faults is better expressed topographically by rectilinear and sharp lineaments than the Fécamp-Lillebonne fault, which shows a curved and smooth topographic signature (Fig. 8).

\section{Pre 1986 collapse data analysis on aerial photos}

\section{Methodology}

Within the 63 sections derived from the fracture analysis, the size of the collapse process was evaluated from the aerial photo interpretation. Several parameters related to the pre-1986 collapses visible in 1986 were collected or calculated:

(1) the total number of pre-1986 collapses per section (PC);

(2) the cumulative scar length (CSL) along the cliff face in each section of a given length;

(3) the percentage of Pre-1986 collapsed cliff surface(PCS), which is the ratio between the cumulative scar length (CSL) divided by the length $(L)$ of the given section;

(4) the percentage of normalized Pre-1986 collapsed cliff surface, which is the ratio between PCS and the total number of pre-1986 collapse in a given section (NPCS). This ratio is given by:

$$
\text { NPCS }=(C S L / L) /(P C)=P C S / P C
$$

For example, in a given cliff section length, high PCS values could be interpreted as a series of smallscars or an isolated huge scar representing an equivalent scar length. Low PCS values could represent the same scar population (a lot of small scars or a huge scar) but it occurs in a larger cliff section. By taking into account the percentage of cumulative collapse length per section, we 
calculated a normalized parameter NPCS which is not dependent of the number of collapse. For example, high NPCS values mean a cliff section with a significant tendency for collapsing whatever the number of collapse. This parameter represents a kind of collapse intensity normalized on the scar length.

Number of Pre-1986 collapses per section (PC)

300 ancient collapses have been recorded from the aerial survey conducted in 1986 (Fig. 9). The average value per section is close to 7 pre-1986 collapses, with a maximum of 27 and two minima of zero. The areas with no collapse correspond to the valleys, with no significant cliff. The map of PC shows three sections with the highest concentrations of collapses, which are located southward of Criel sur Mer, westward of St Valéry-en-Caux and southward of Vaucottes, with the maximum PC southward of Criel sur Mer, between Val Pollet and Penly. The two minima are located north of St Pierre-en-Port valley and north of Dieppe up to Puys in a 50-m height cliff. The sections with high to moderate collapse concentrations do not show a preferential distribution. The PC is not related to the well-known regional faults. There is no significant concentration of ancient collapses in the vicinity of the Eu, Bray and Fécamp-Lillebonne faults (Fig. 9). On the contrary, the highest PC values are located far away from the regional faults. The number of collapses is therefore not directly related to the paleotectonic activity.

Percentage of Pre-1986 collapsed cliff surface per section (PCS)

By ignoring the valleys, the average value of the PCS rate is $21 \%$. The map of PCS shows three main areas, from SW to NE (Fig. 9): (1) the highest PCS values are located between Le Tilleul and Veulesles-Roses, with the maximum value (66\%) located south to Fécamp; (2) the lowest PCS rates are located between Veules-les-Roses and Dieppe; and (3) North of Dieppe, PCS rates are intermediate. The PCS is not systematically related to the location of regional faults. For the Bray and the Eu faults, there is no spatial correlation, whereas for the Fécamp-Lillebonne fault, the PCS value is rather high. The low PCS values are located far away from the regional faults. 
The average value of NPCS rates is about 5\%. By normalising the PCS, extreme values are reinforced and minima and maxima alternate spatially (Fig. 9). Three maxima located at Fécamp, Dieppe and Mers-les-Bains are clearly identified. The minima are located south of Yport, between St Martin aux Buneaux and Dieppe, and from Puys to Criel sur Mer.

The high NPCS values mimic the regional fault locations, whereas the low NPCS values are located far from the regional faults. The NPCS rate is the most relevant parameter for characterising the ancient collapse intensity, because it takes into account the collapse size effect (small to large sizescar), the section dimension (horizontal length) and the number of events (i.e. number of ancient collapses).

Several points arise from this part of the study. TFT spacing distribution and NPCS values are both spatially correlated with the location of the regional faults. Fractures visible in the cliff and ancient collapses are also correlated for the maximum values. This correlation is not well constrained for the minimum and intermediate values. For example, between Dieppe and Veules-les-Roses, the NPCS values are very low whereas the TFT values are moderate. By considering only the large-scale fractures (MFT), the spatial correlation between pre-1986 collapses and fractures is less clear than for the whole fracture population (MFT). At a regional scale, the pre-1986 collapse distribution derived from aerial photos and the whole fracture distribution is spatially correlated to the regional faults of Fécamp-Lillebonne, Bray and Eu.

\section{Recent collapses analysed from field observation}

Between 1998 and 2001, a minimum of 55 cliff collapses of various size has been recorded along the coastline of Upper-Normandy and Picardy (Fig. 10). About 75\% of them correspond to large-scale collapses, which affect the whole cliff height. $70 \%$ of the recent collapses occurred in 2001 and are mainly interpreted as a consequence of high rainfall (Duperret et al., this volume). Recent collapses are not equally spaced along the coastline, some areas with high concentrations alternating with areas of low concentrations creating a clustered distribution pattern. Between Veules-les-Roses and cap d'Ailly, many collapses have been observed (mainly small-scale failures). However, the sampling of collapse data was unequal because it was not possible to record continuously the entire coastline. It is 
for this reason there are a lot of small-scale collapses between Veules-les-Roses and cap d'Ailly, this section being fully surveyed in the field. This is also the reason why only larger collapses are recorded everywhere else, whereas the small ones are missing.

In order to evaluate the role of the pre-existing fractures on recent collapse location, the fracture content controlling or not the scar collapse, as well as those embedded within the scar, has been analysed. Based on the recent collapse database, field observations show that $40 \%$ of the collapses are not bounded laterally by pre-existing fractures, $55 \%$ are bounded by at least one fracture and $5 \%$ are bounded by two fractures. $58 \%$ of the recent collapses show no significant pre-existing fractures within the scar. Stress release fractures could exist but they were not observed. An example of a recent collapse limited by a pre-existing fracture is presented in Fig. 11. As the fractures observed within the collapse are generally transverse fractures relatively orthogonal to the cliff face, we assume that they do not create the collapse trigger. They could represent either mechanical barrier by halting the lateral progression of failure scar or behave as a passive mechanical structure when they are developed inside a given scar.

The number of collapses observed on the cliff face in 1986 is 6 times higher than those observed during three years (1999-2001). However, between St Aubin sur Mer and Quiberville, recent collapses are more numerous but they mainly correspond to small-scale collapses (Fig. 12). As this section was better sampled during the field survey, this result is not significant in terms of degree of erosion. In the other sections, small-scale collapse inventories were underestimated as well as the related degree of erosion. Actually, the collapses reported in 1986 correspond to the footprints of successive collapse events visible as scars on our photograph that may have occurred a few years before the observation, whereas collapses reported between 1998 and 2001 are better constrained in terms of time of occurrence. There is consequently a significant uncertainty for the real timing of occurrence for collapses identified on the aerial photos taken in 1986. Those photos probably contain some collapse marks, which occurred several years before 1986, increasing the pre-1986 collapse number. The coastal sections having a higher number of collapses in 1986 do not match with those defined between 1998 and 2001. For example, between Fécamp and Eletot, no collapse is observed between 1998 and 2001, whereas about 20 collapses are recorded from the 1986 aerial photographs. 
The comparison between the two survey periods suggests a different spatial evolution of collapse events along the coast. The areas active in 1986, are not exactly the same as those observed in 19982001. The results suggest that the erosion by collapse is not continuous in space and time, but occurs suddenly at different locations and at different time periods. The absence of long-term observations reduces the accuracy of conclusions that can be drawn from this study.

\section{Discussion}

The erosion of the coastal chalk cliffs of Upper-Normandy and Picardy is mainly controlled by collapses of various sizes. From Le Tilleul to Ault, the coastline is made of three large-scale linear segments oriented N60E (from Le Tilleul to Veulettes sur Mer), N80E (from Veulettes sur Mer to Dieppe) and N50E (from Dieppe to Ault) (Fig. 13). The N60E and N50E coastal segments present the same chalk succession, whereas the N80E segment is completely different from a lithological point of view (Duperret et al., this volume). As the dominating fracture set observed both from regional scale, aerial photos and field observations is oriented normally to the coastline, the coast is not directly controlled by this regional fracture orientation. A secondary fracture set roughly parallel to the coastline has been observed, but only locally, and does not seem to influence the coastline orientation. Therefore, as field observation shows, the chalk cliffs are not affected by a systematic fracture set parallel to the coastline and the observed collapses are not directly linked to this fracture orientation. However, we infer that stress release fractures newly created and parallel to the cliff face could be a control on some collapse mechanisms. The fractures orthogonal to the coastline are dominant, but their orientation does not tend to favour a cliff collapse, from a geometrical point of view. A part of these fractures may limit the lateral extension of the collapse on the cliff face, by forming mechanical barriers.

The erosion of the coastal chalk cliffs could be also derived from the whole fracture density. The fracture density is heterogeneously distributed along the coastline, the maxima being linked to the regional faults. As the fracture density correlates better to areas with more pre-1986 collapses than the large-scale fracture density, this suggests that the full ranges of fracture sizes are involved in the 
collapse process. The impact of the fracture density on the cliff collapses can be deciphered by analysing the coastal orientation in relation with the fracture content. Coastal segments with the higher fracture density are mainly oriented N60E (around the Fécamp-Lillebonne fault) and N50E (northward of the Bray fault). In that case, the coastline is roughly perpendicular to the main fracture orientation. Coastal segments with a low fracture density are mainly oriented N80E (between Veulettes sur Mer and Dieppe). In that case, there is no dominating fracture set and the orientation of the coastline could be controlled mainly by the chalk lithology (Fig. 13).

In spite of the uncertainties related to the collapse data acquisition, both from aerial photos and field measurements, the collapse datasets $(1986,1998-2001)$ show different responses along the coastline. The pre-1986 collapses are correlated with the regional fault location and the fracture content, whereas the recent collapses do not show the same spatial relationship with fracture content. We thus suppose that this discrepancy is due to the superimposition of some other parameters (rainfall, marine erosion, ...) or to the recent collapse sampling period, which is probably too short in relation to the long-term erosion process. The coastal erosion by collapse is difficult to measure on short-term periods (for example, three years) because cliff collapses are spatially and temporally variable and discontinuous.

The role of fractures on collapse occurrence is determined by means of observations conducted over two time periods and a multiscale fracture analysis. Some fracture characteristics (filling, aperture, rugosity, channelling) have not been investigated which could influence collapse characteristics (location, size, triggering effect). For instance, according to the nature of the fracture filling (impermeable clays, karstic network), a fracture could be well drained or undrained and consequently could influence collapse mechanism.

\section{Conclusion}

Multi-scale fracture analysis, based on field survey and aerial photograph interpretation, was used to investigate erosion by cliff collapse of the Upper Cretaceous Chalk coastline of NW France. The field survey provided a control on observations derived from aerial photographs and provided a more 
detailed fracture and collapse data not obtainable from aerial photographs. The coastline is divided into 63 sections derived from fracture analyses within which cliff collapse processes have been evaluated. A new method of delineating the extent of cliff erosion within sections of cliff is based on total number of collapses (PC), cumulative cliff failure scar width, percentage of pre-1986 collapsed cliff surface (PCS) and on percentage of normalized pre-1986 collapsed cliff surface (NPCS). The NPCS in particular helps identify where maxima and minima in cliff collapse erosion are located. In addition, the results of applying the NPCS to the $120-\mathrm{km}$ of coastline illustrate the importance of major structural features (the major faults at Fécamp, Bray and Eu) in the location of maxima and minima. At a local scale, in contrast to the aerial photograph analyses, the field study of recent collapses suggests no systematic correlation of cliff collapse and fracture occurrence.

Fracture evaluation shows that the dominating fracture set is N120E and this corresponds mainly to normal faults roughly perpendicular to the coastline orientation. Several secondary fracture sets have been identified one of which is locally parallel to the coastline. Field observations have shown three relationships between fractures and the scars left by cliff collapses (i) fractures limit the scar laterally (ii) fractures are located only within the scar (iii) no pre-existing fractures are involved in the scar.

The study also illustrates the differences in location, frequency and structural interpretation of cliff collapses between two periods of observation (pre-1986 and 1998-2001) and the need, therefore, for a long and detailed historical record of cliff collapses before final conclusions can be drawn about the mechanisms, frequency, location and size of cliff collapses.

\section{Acknowledgements}

The ROCC project was funded by the European community through the INTERREG II Rives-Manche community initiative (contract 199059). This research work has also been partly funded by the Centre National de la Recherche Scientifique in the framework of Programme National des Risques Naturels, through the contract PNRN 99-35-AS, by the Regional Council of Somme, the French Geological Survey (BRGM) and the University of Brighton. We thank the Maritime Direction Départementale de l'Equipement at Dieppe for providing us with oblique aerial photographs of the French coastline. The authors thank W. Murphy for a very helpful review. 


\section{References}

Bristow, R., Mortimore, R.N., \& Wood, C.J. 1997. Lithostratigraphy for mapping the chalk of southern England. Proceedings of the Geologist's Association, 109, 293-315.

Costa, S. 2000. Le recul des falaises du pays de Caux. Bulletin d'Information des Géologues du Bassin de Paris, $\mathbf{3 7}, \mathrm{n}^{\circ} 1,31-34$.

Dikau, R., Brunsden, D., Schrott, L., Ibsen, M-L. 1996. Landslide recognition, identification, movement and causes, International Association of Geomorphologists, Wiley Ed., 243 p.

Dornbusch, U., Williams, R.B.G., Robinson, D.A., \& Moses, C. 2001. Disappearing act : Contribution of cliff erosion and in situ abrasion of flint to the shingle budget on the East Sussex coast, European Rock Coasts 2001 conference, Brighton, UK, 17-18 December 2001.

Duperret, A., Genter, A., Mortimore, R.N., Delacourt, B., \& De Pomerai, M. 2002. Coastal rock cliff erosion by collapse at Puys, France: the role of impervious marl seams within chalk of NW Europe. Journal of Coastal Research, 18, $\mathrm{n}^{\circ} 1,52-61$.

Duperret, A., Genter, A., Martinez, A., \& Mortimore, R.N. this volume. Coastal chalk cliff instability in NW France : the role of lithology, fracture pattern and rainfall, in : Mortimore R.N. and Duperret A. (eds), Coastal Chalk Cliff Stability, Geological Society, London, Special Publications.

Hibsch, C., Cushing, M., Cabrera, J., Mercier, J., Prasil, P., \& Jarrige, J-J. 1993. Palaeo-stress evolution in Great Britain from Permian to Cenozoic : a microtectonic approach to the geodynamic evolution of the southern UK. Basins. Bull. Cent. Rech. Explor. Prod. Elf Aquitaine, 17 (2), 303-330.

Hibsch, C., Jarrige, J-J, Cushing, E.M., \& Mercier, J. 1995. Palaeostress analysis, a contribution to the understanding and geodynamic evolution : Example of the Permian/Cenozoic tectonics in Great Britain and geodynamic implications in western Europe., Tectonophysics, 252, 103-136.

May, V.J. 1971. The retreat of chalk cliffs, Geographical Journal, 137, 203-206.

Mortimore, R.N. 1983. The stratigraphy and sedimentation of the Turonian-Campanian in the Southern Province of England. Zittelania, 10, 27-41.

Mortimore, R.N. 1986. Stratigraphy of the Upper Cretaceous White chalk of Sussex. Proceedings of the Geologist's Association, 97, 97-131. 
Mortimore, R.N., \& Pomerol, B. 1987. Correlation of the Upper Cretaceous White chalk (Turonian to Campanian) in the Anglo-Paris Basin. Proceeding of the Geologist's Association, vol. 98, part 2.

Mortimore, R.N., Pomerol, B., \& Foord, R.J. 1990. Engineering stratigraphy and palaeogeography for the chalk of the Anglo-Paris Basin. In : Chalk, Thomas Telford (ed), London.

Mortimore, R.N., Lawrence, J., Pope, D., Duperret, A., \& Genter, A. this volume. Coastal cliff geohazards in weak rock : the UK Chalk cliffs of Sussex, in : Mortimore R.N. and Duperret A. (eds), Coastal Chalk Cliff Stability, Geological Society, London, Special Publications.

Pomerol, B., Bailey, H.W., Monciardini, C., \& Mortimore, R.N. 1987. Lithostratigraphy and biostratigraphy of the Lewes and Seaford chalks : A link across the Anglo-Paris Basin at the Turonian-Senonian boundary. Cretaceous Research, 8, 289-304.

Vandycke, S. 1992. Tectonique cassante et paléo-contraintes dans les formations crétacées du NordOuest européen. Implications géodynamiques. Thèse de l'Université de Paris VI, 180 p.

Vandycke, S., \& Bergerat, F. 1992. Tectonique de failles et paléo-contraintes dans les formations crétacées du Boulonnais (France). Implications géodynamiques. Bull. Soc. Géol. France, 163, n5, 553-560.

Vila, J.L. 2000. Étude du littoral cauchois : méthode descriptive des falaises côtières à partir des photos aériennes obliques dans l'optique de l'évaluation de leur sensibilité à l'érosion. Rapport de DESS «Télédétection, méthodes, application, environnement ». Université Pierre et Marie Curie, Paris.

\section{Figure Captions}

Fig. 1 : Location of the fracture sites investigated at field scale, on the French coastline of UpperNormandy and Picardy

Fig. 2 : Rose diagrams of fracture azimuth collected on the cliff face $(A)$ and on the beach platform (B) at Bois de Cise. Rose diagrams of stratabound fracture azimuth collected on the cliff face at Eletot (C) and Senneville sur Fécamp (D) 
Fig. 3 : Conceptual model of the fracture system embedded within the chalk of Upper-Normandy and Picardy (map view) based on field survey

Fig. 4 : Example of an oblique aerial view (shot taken in 1986) of the French coastline (on the left, Bois de Cise area), with its main features

Fig. 5 : Location of the detailed coastal sections analysed on the field between St Valéry-en-Caux (SW) and Pourville (NE) and fracture location

Fig. 6 : Stereographical projections (Schmidt plot in lower hemisphere) of the fractures collected on the field between St Valéry-en-Caux and Pourville. A: master-joints, B: normal faults, C: synsedimentary fractures

Fig.7 : Example of fracture density sectoring along the cliff face. Each sector having a given fracture organisation is characterized by its linear fracture density or its fracture spacing. This section is oriented NE-SW, i.e. Bois de Cise to Mers les Bains

Fig. 8 : Fracture density based on aerial photos, between Le Tilleul and Ault on the chalk coastline of NW France. TFT (Total Fracture Types) strip : mean fracture spacing in each coastal sectors for all the fracture types. MFT (Main Fracture Types) strip : mean fracture spacing in each coastal sectors for large-scale fractures only

Fig. 9 : Map of pre-1986 collapse data recorded in 1986 from aerial photographs, between Le Tilleul and Ault on the chalk coastline of NW France. NPC, Number of Pre-1986 Collapse, in each coastal sector. PCS, Percentage of Pre-1986 Collapsed Cliff Surface, per section. NPCS, Percentage of Normalized Pre-1986 Collapsed Cliff Surface, per section

Fig. 10 : Location of recent collapses recorded on the field between October 1998 and December 2001. The size of the circles is proportional to the size of the collapse. The grey scale within the circles indicates the year of collapse occurrence 
Fig. 11 : Example of recent collapse at St Pierre en Port, that occurred on March the $15^{\text {th }} 2001$, showing a scar bounded laterally by a pre-existing vertical fracture. The total cliff height is about $90 \mathrm{~m}$

Fig. 12 : Comparison between the Number of Pre-1986 Collapses (NPC) observed in 1986 on aerial photos and the number of collapses observed on the field between 1998 and 2001

Fig. 13 : Schematic sketch of the coastline orientation versus regional faults in upper Normandy and Picardy

Table 1 : Characteristics of the sites investigated for fracture evaluation

Table 2: Fracture dataset characteristics collected on the cliff face and on the beach platform 


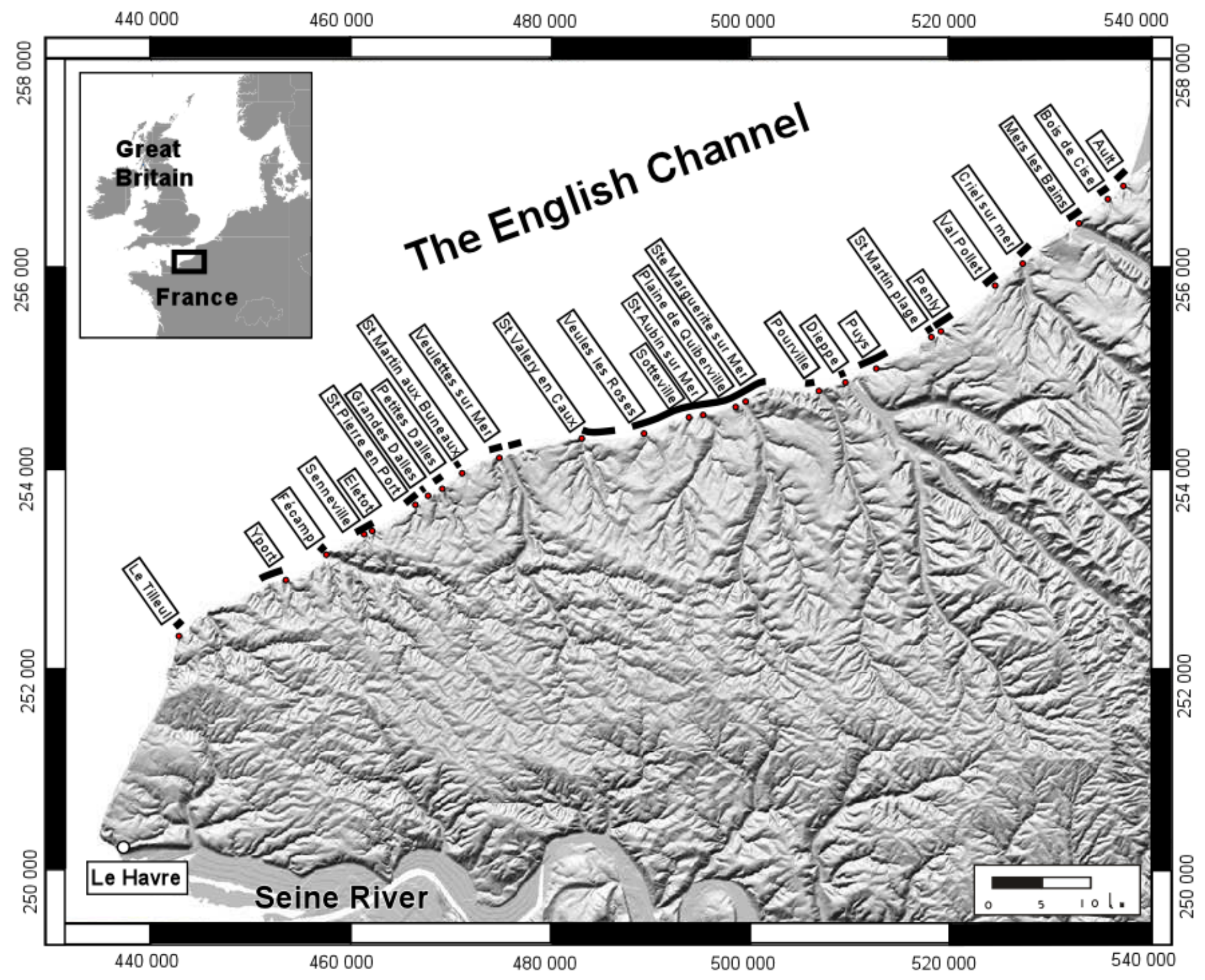




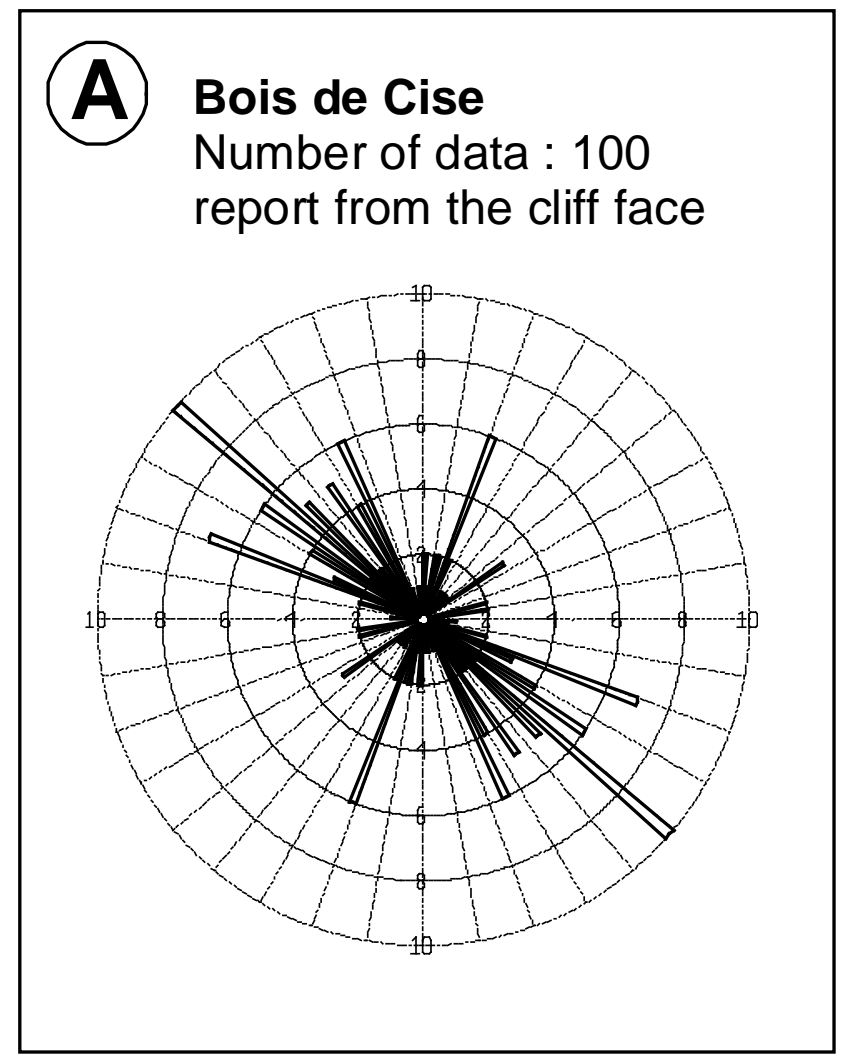

\section{(B) Bois de Cise \\ Number of data : 123 \\ report from the beach platform}

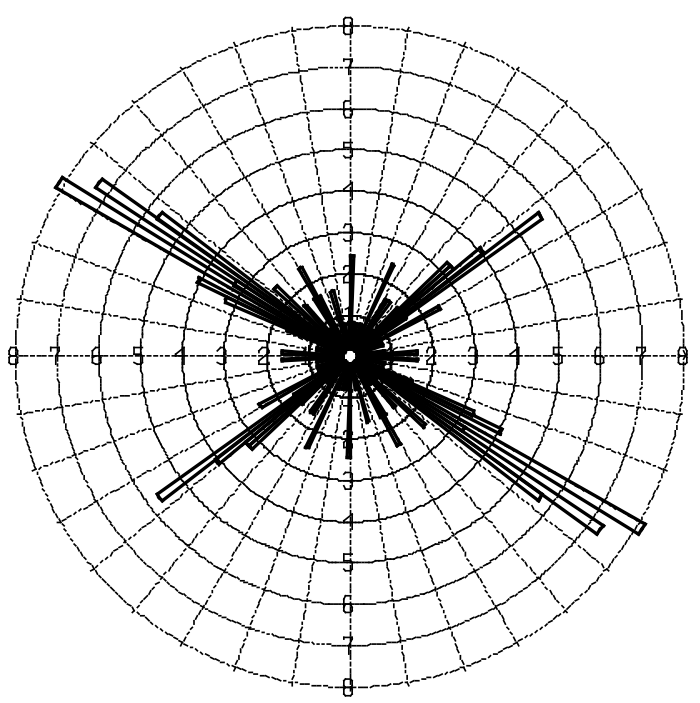

\section{Eletot (North)}

Number of data : 54

report from the cliff face

(only normal faults)

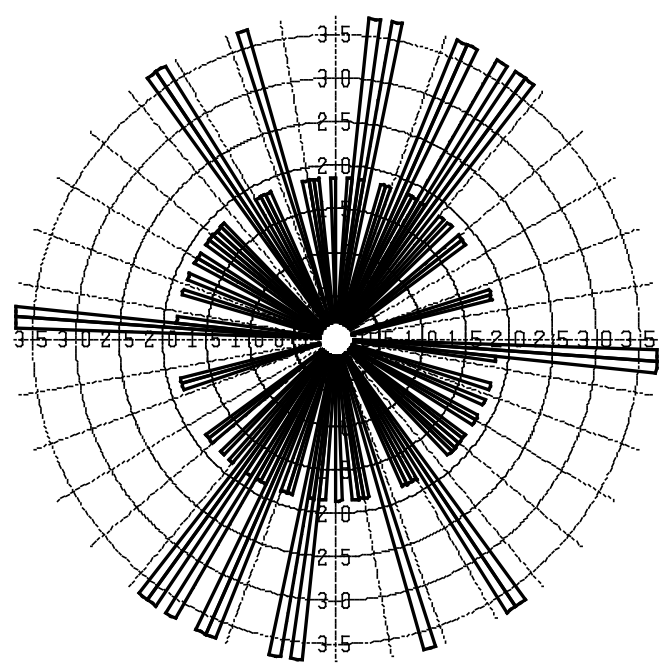

Senneville (South)

Number of data : 32

report from the cliff face

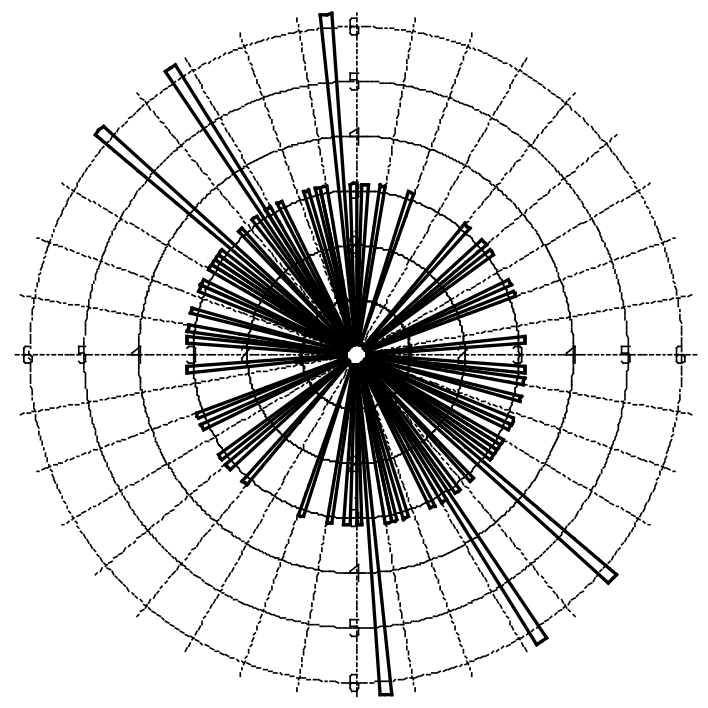




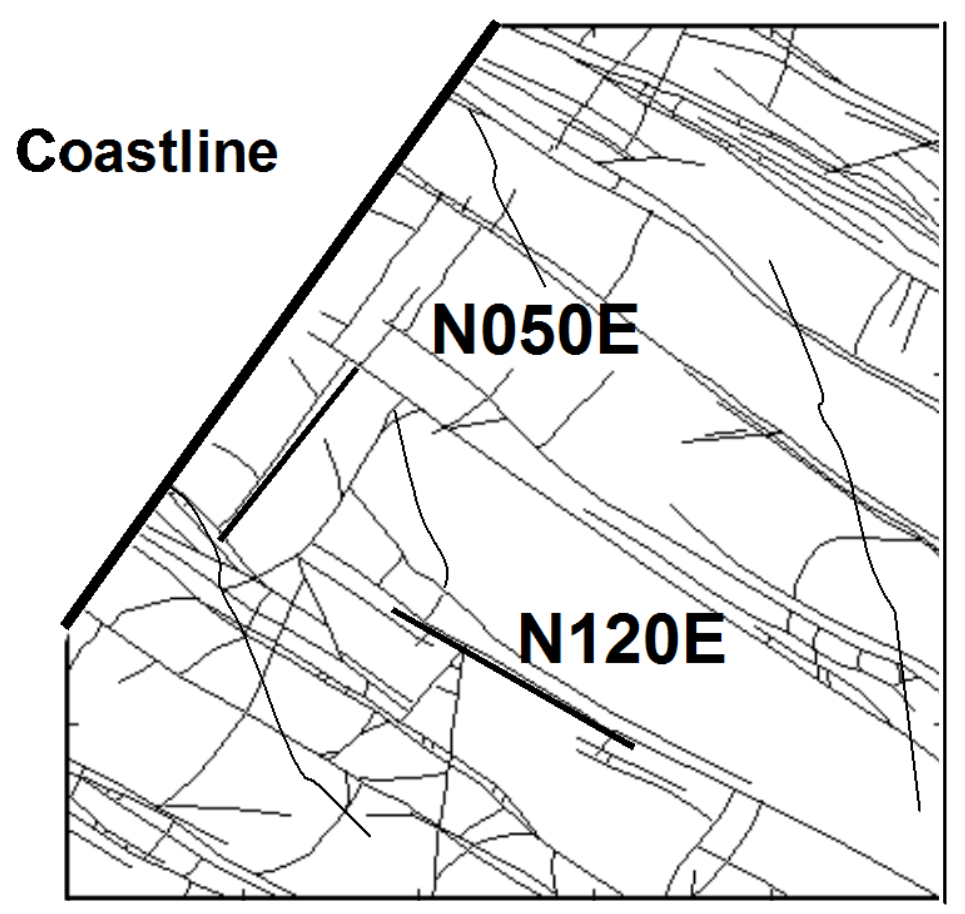




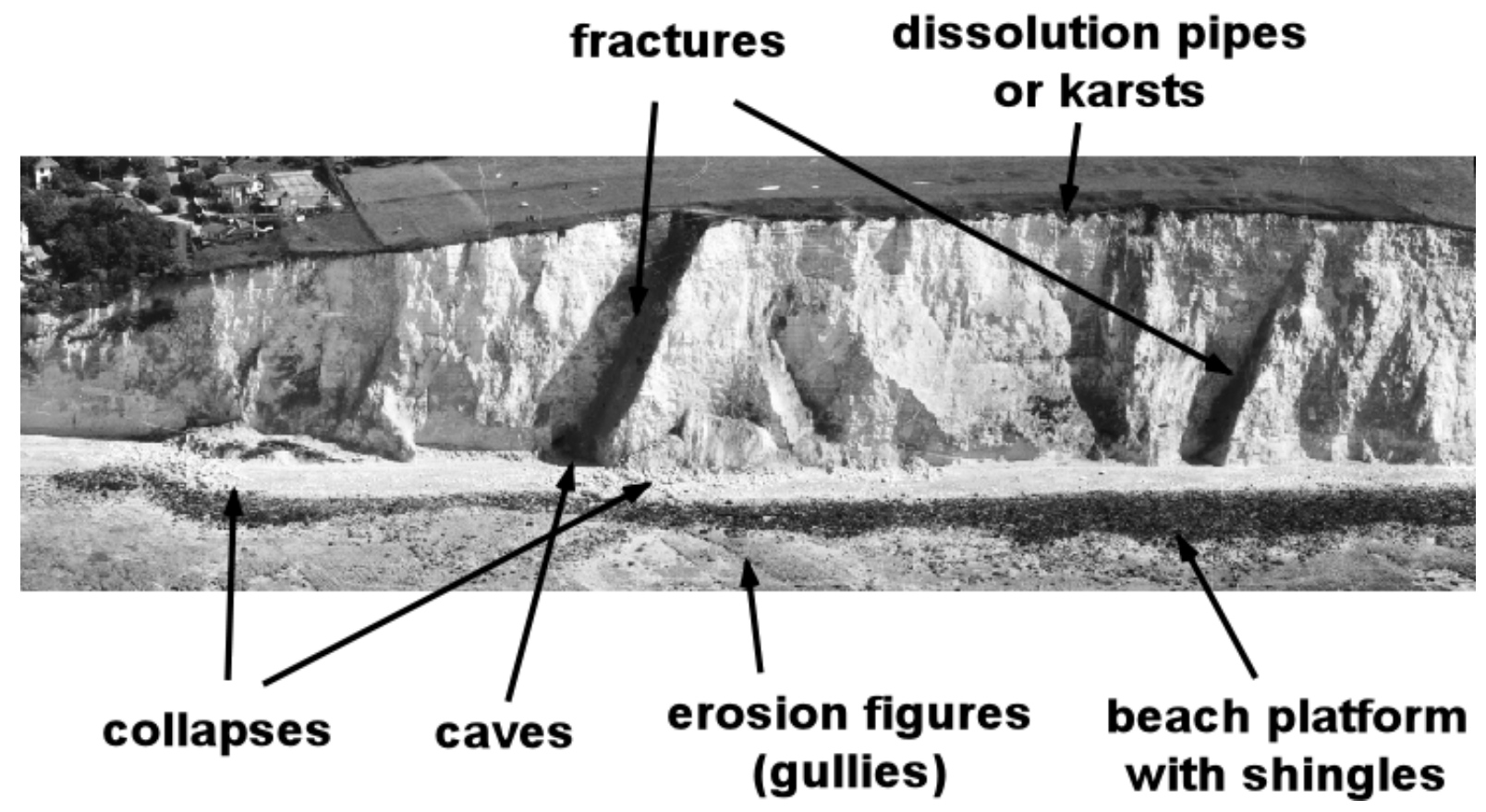


$\square \quad$ Investigated zone during the field work

St Aubin
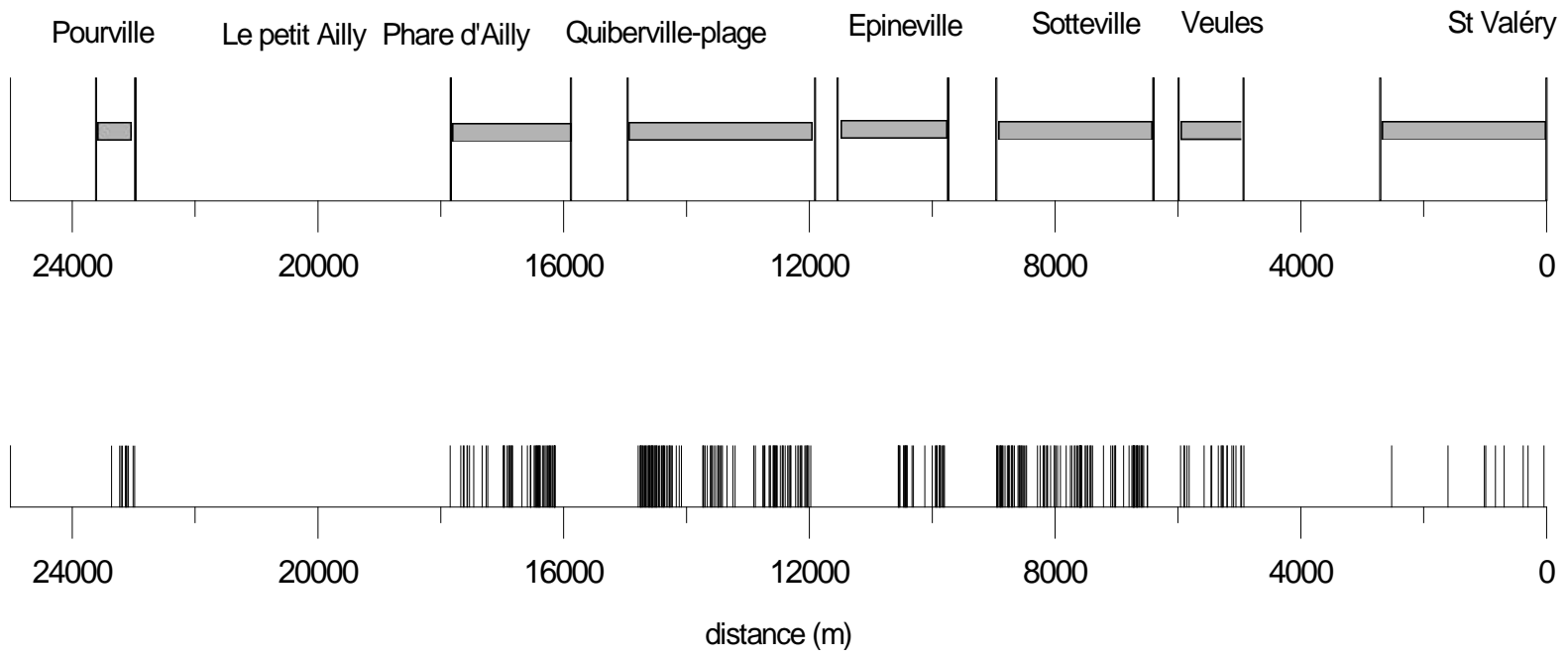


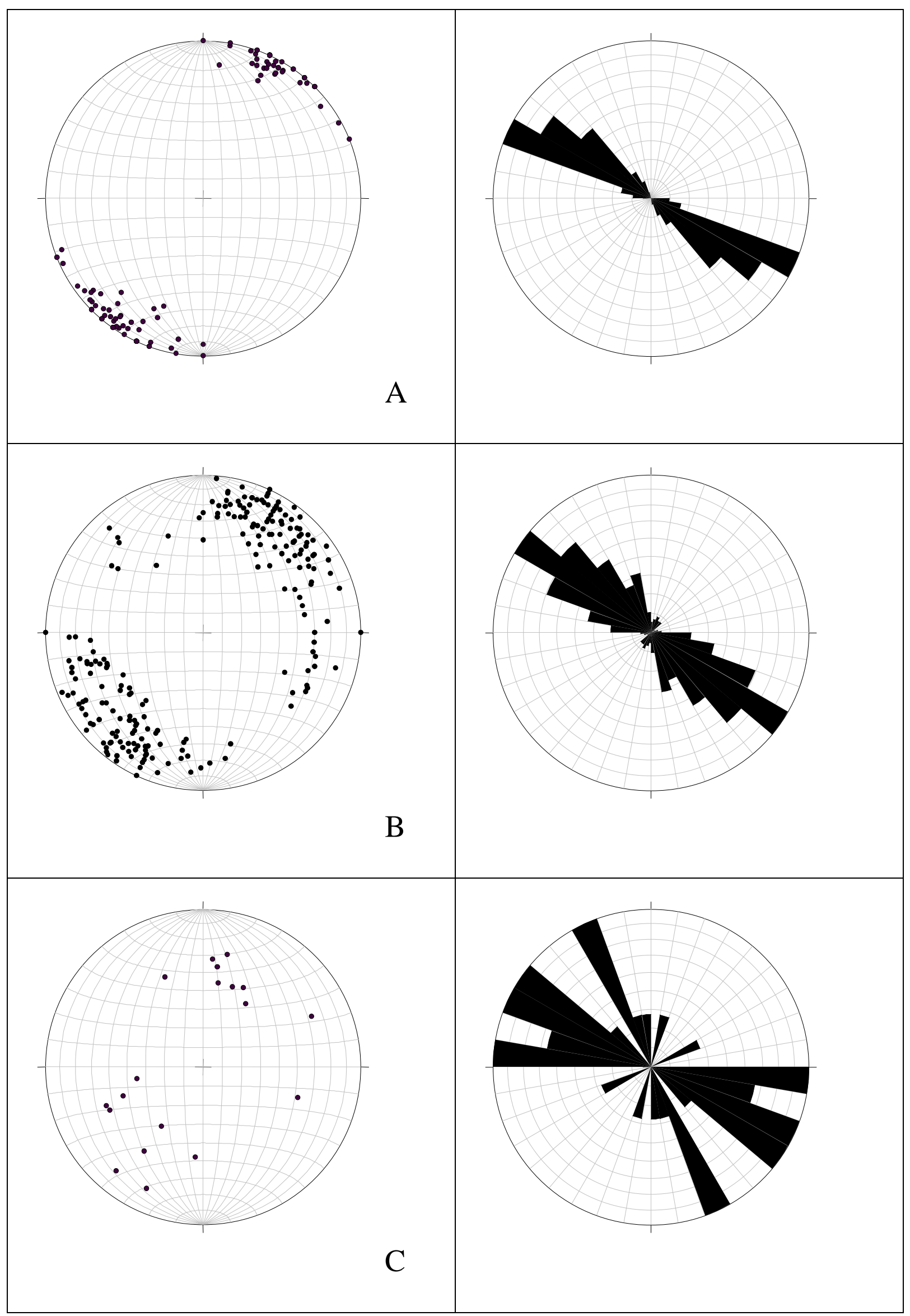

Fig. 6, Genter et al., 2002 


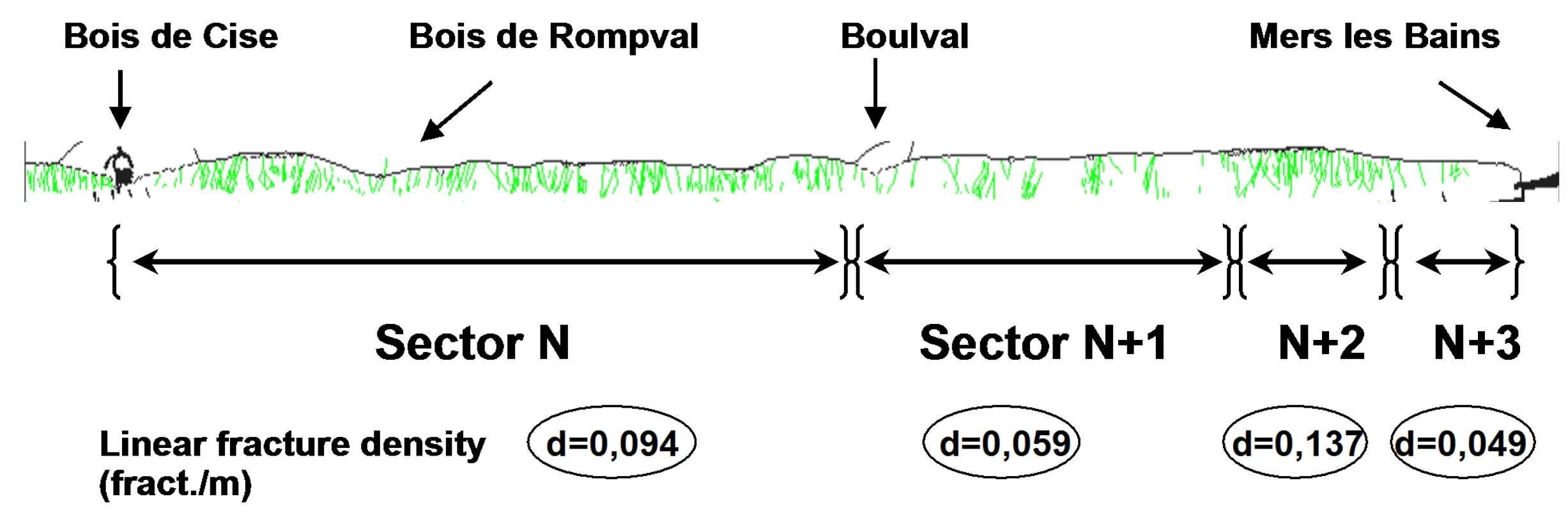




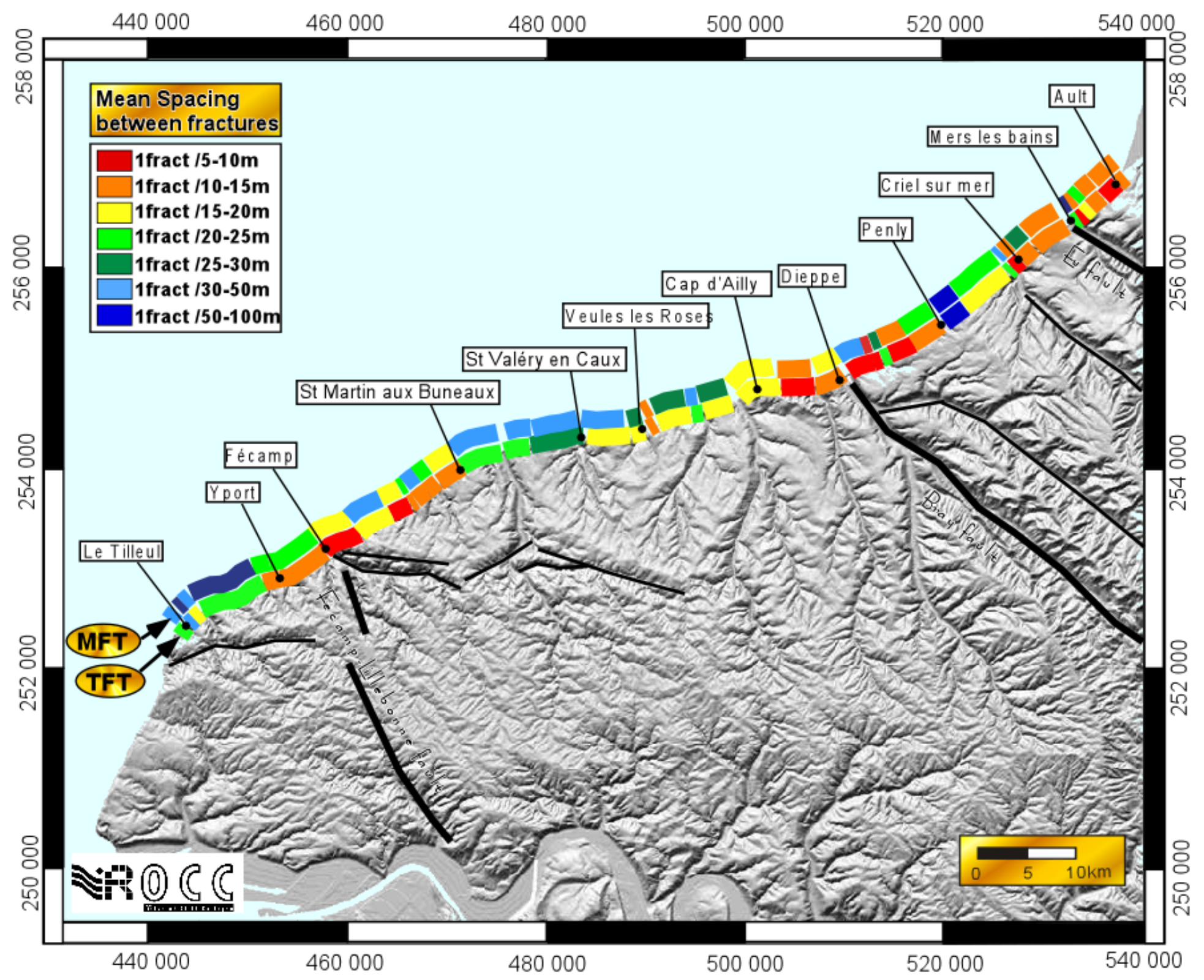




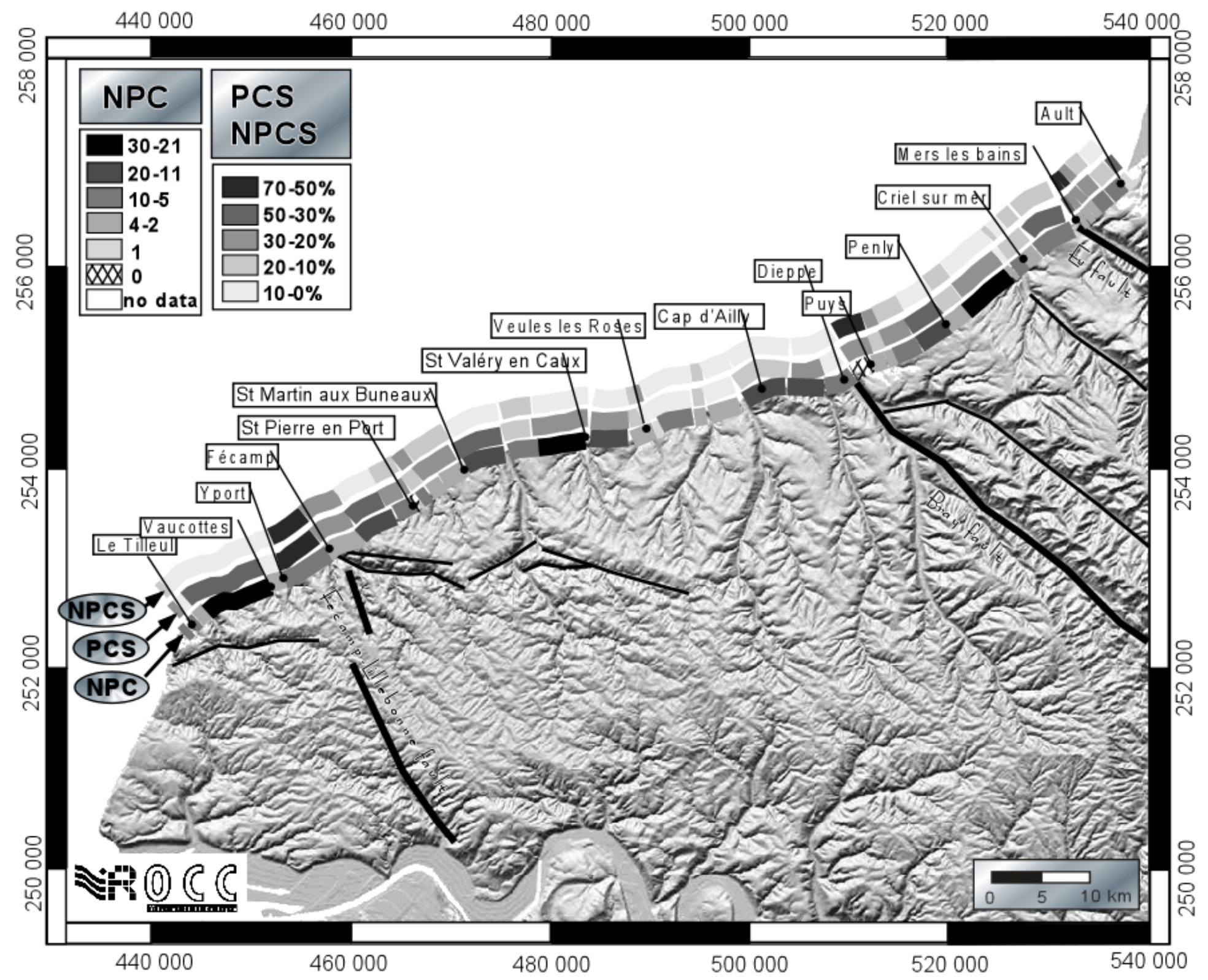




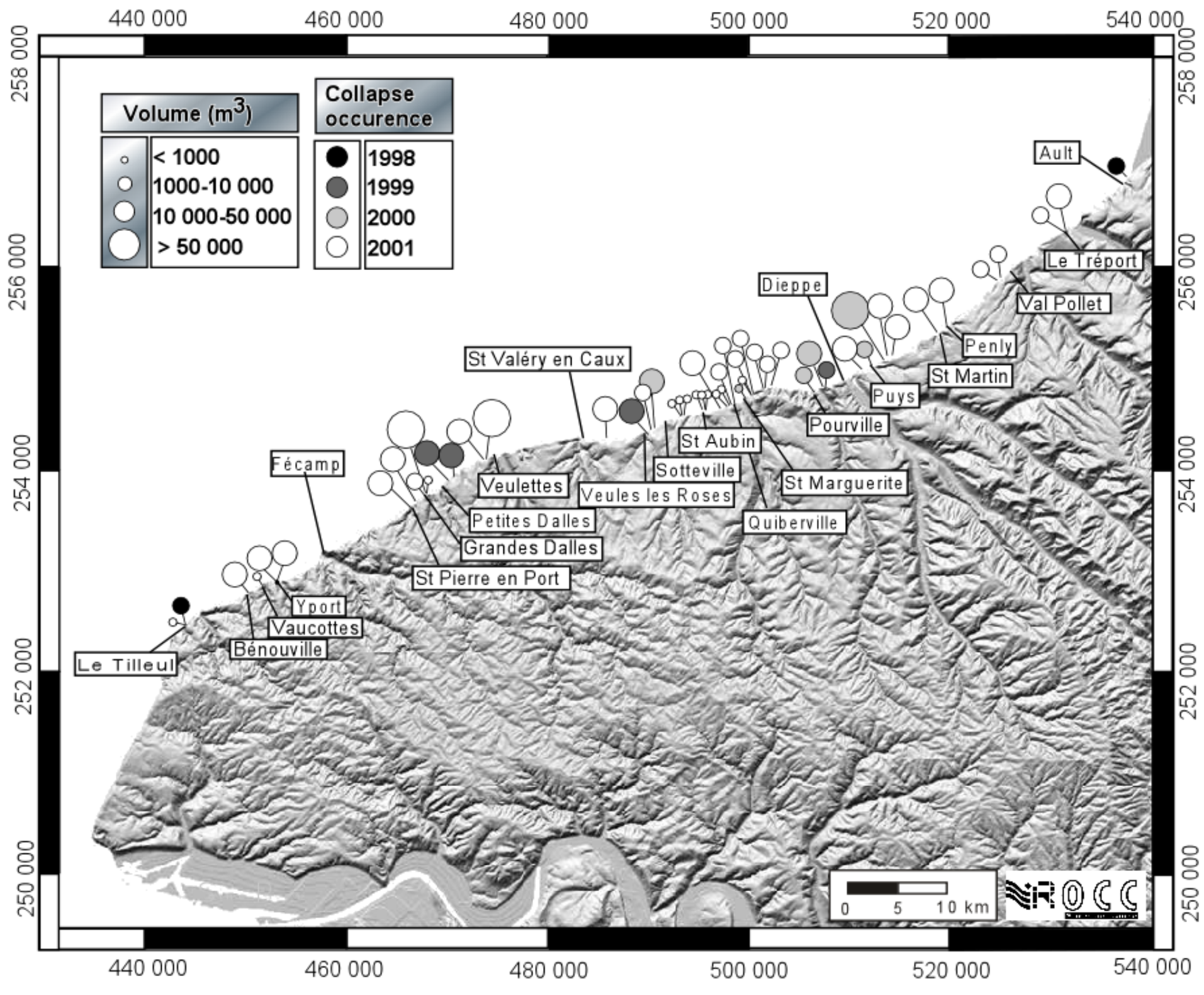





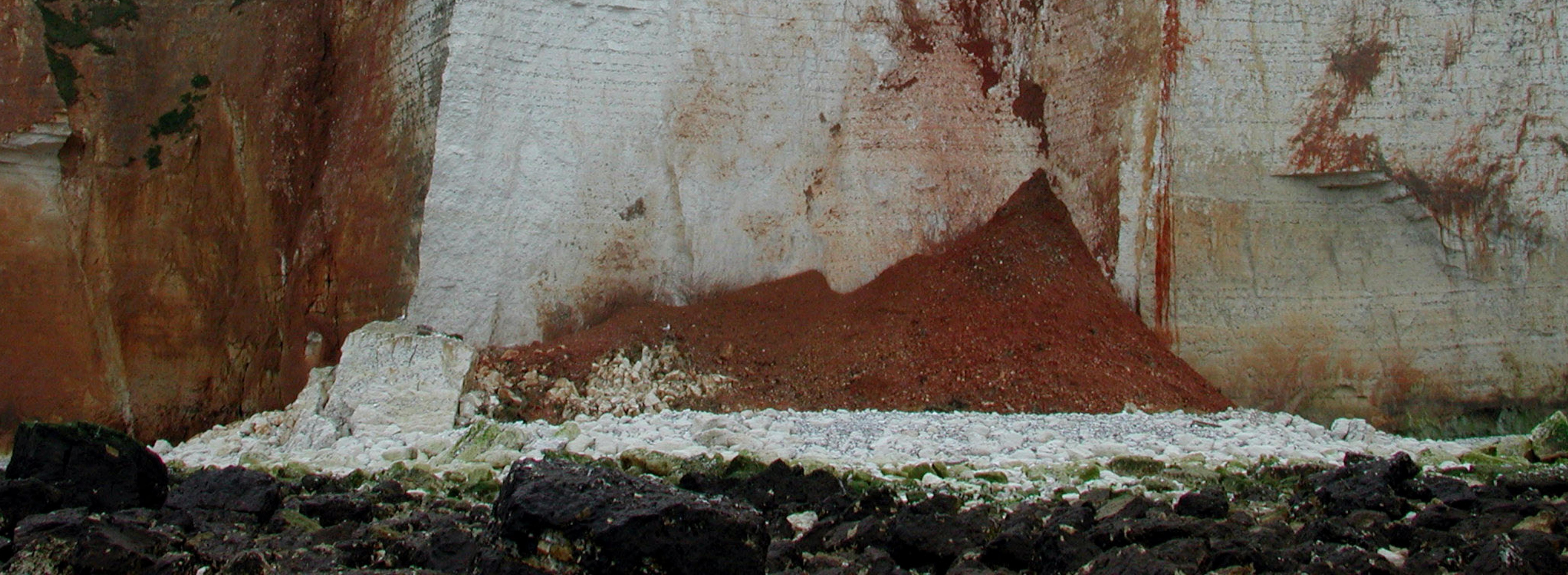




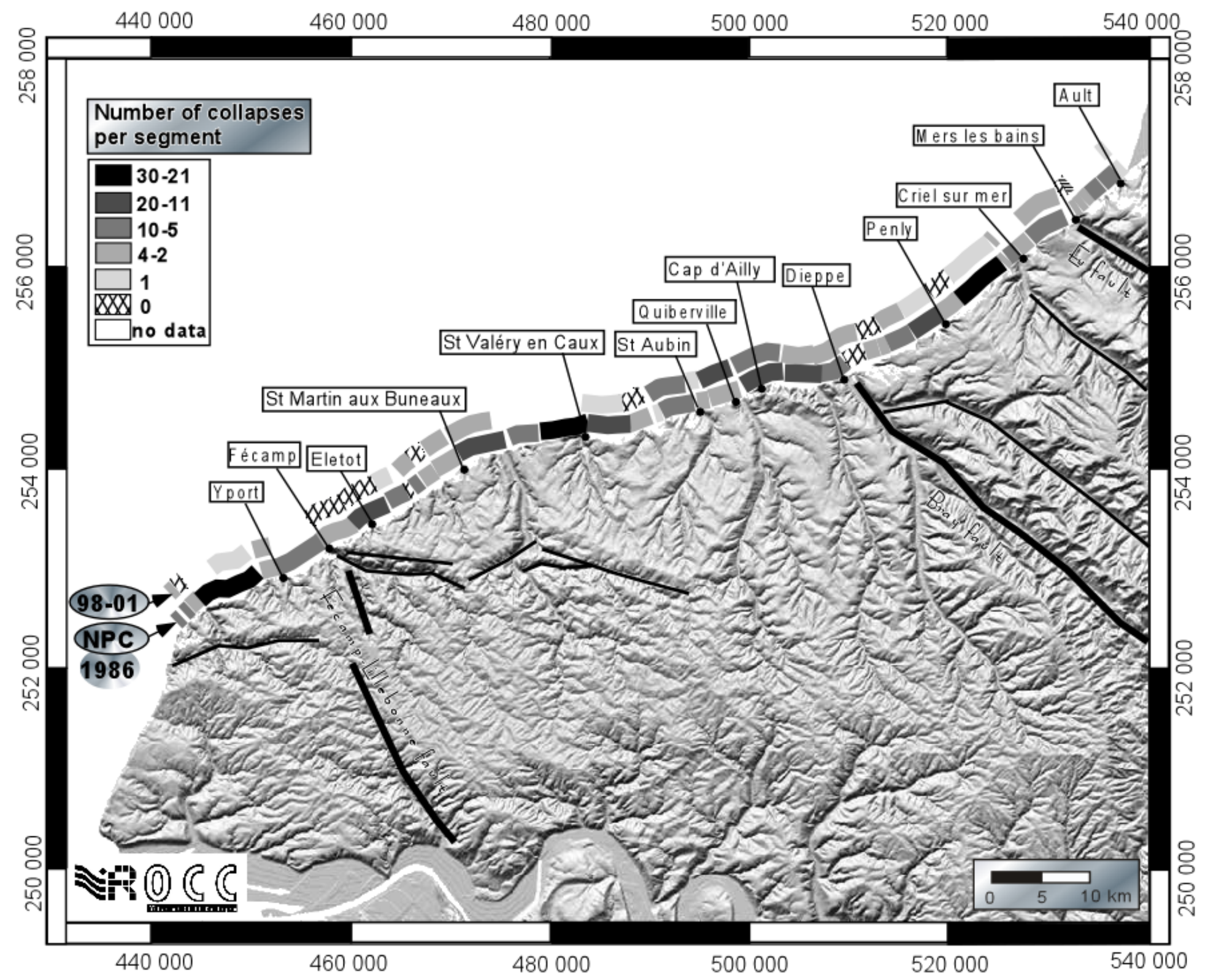




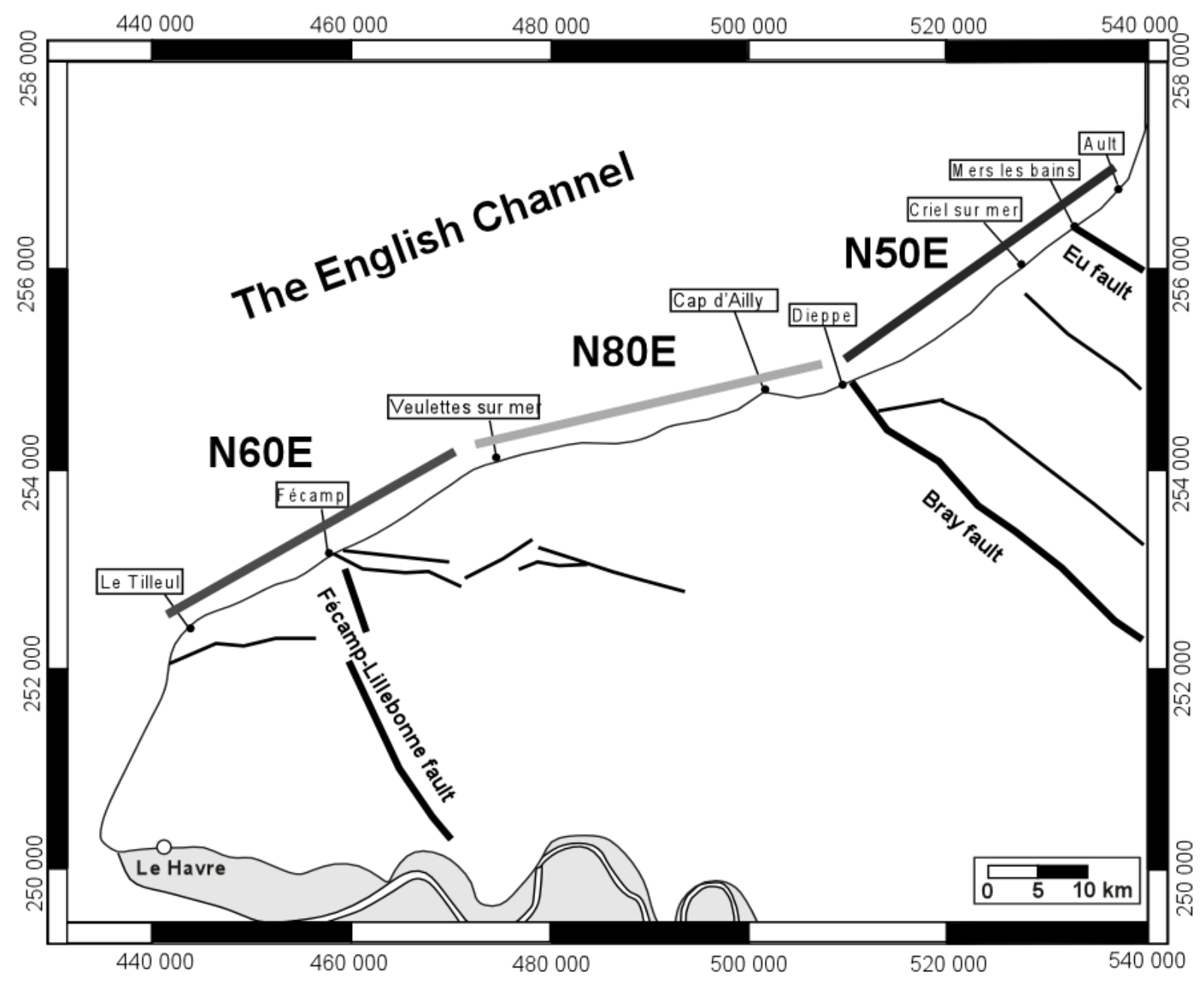




\begin{tabular}{|c|c|c|c|c|c|}
\hline Investigated site & \begin{tabular}{|c|} 
Number of \\
lithological units \\
on the cliff
\end{tabular} & \begin{tabular}{|c|} 
Name of the lithological \\
units (from Mortimore, \\
1983)
\end{tabular} & Cliff orientation & $\begin{array}{c}\text { Strucural } \\
\text { data } \\
\text { collected on } \\
\text { the cliff }\end{array}$ & $\begin{array}{l}\text { Strucural data } \\
\text { collected on } \\
\text { the beach } \\
\text { platform }\end{array}$ \\
\hline Ault Nord & 2 & Lewes et Seaford & $\mathrm{N} 40$ & 32 & 0 \\
\hline Ault S & 2 & Lewes et Seaford & $\mathrm{N} 40$ & 34 & 0 \\
\hline Bois de Cise N & 2 & Lewes et Seaford & N45 & 100 & 123 \\
\hline Mers les Bains $\mathrm{N}$ & 2 & Lewes et New Pit & N50 & 8 & 0 \\
\hline Criel sur Mer N & 2 & Lewes et Seaford & $\mathrm{N} 40$ & 78 & 0 \\
\hline Criel sur Mer S & 2 & Lewes et Seaford & N60 & 29 & 0 \\
\hline Val Pollet & 2 & Lewes et Seaford & N50 & 16 & 0 \\
\hline Penly N & 3 & $\begin{array}{l}\text { Holywell, New Pit, } \\
\text { Lewes }\end{array}$ & N45 & 25 & 30 \\
\hline St Martin N & 3 & $\begin{array}{l}\text { Holywell, New Pit, } \\
\text { Lewes }\end{array}$ & N45 & 83 & 0 \\
\hline Puys $\mathrm{N}$ & 1 & Lewes & $\mathrm{N} 60$ & 61 & 0 \\
\hline Puys S & 1 & Lewes & N70 & 13 & 0 \\
\hline Dieppe S & 1 & Seaford & N60 & 17 & 0 \\
\hline Pourville S & 1 & Newhaven & N95 & 12 & 0 \\
\hline Quiberville N & 1 & Newhaven & N50 & 58 & 0 \\
\hline St Aubin sur Mer N & 1 & Newhaven & N70 & 104 & 0 \\
\hline Epineville & 1 & Newhaven & N65 & 16 & 0 \\
\hline Sotteville La Pointue & 1 & Newhaven & N55 & 93 & 0 \\
\hline Veules les Roses $N$ & 2 & Seaford et Newhaven & N55 & 23 & 0 \\
\hline Veules les Roses S & 1 & Seaford & N75 & 21 & 0 \\
\hline St Valéry en Caux N & 1 & Seaford & N85 & 9 & 43 \\
\hline Veulettes sur Mer $\mathrm{N}$ & 2 & Lewes et Seaford & N50 & 10 & \\
\hline Veulettes sur Mer S & 2 & Lewes et Seaford & N90 & 30 & 85 \\
\hline St Martin aux Buneaux & 2 & Lewes et Seaford & N55 & 17 & 0 \\
\hline Les Petites Dalles N & 2 & Lewes et Seaford & $\mathrm{N} 40$ & 65 & 93 \\
\hline Les Grandes Dalles S & 2 & Lewes et Seaford & & & 14 \\
\hline St Pierre en Port N & 2 & Lewes et Seaford & $\mathrm{N} 40$ & 47 & 32 \\
\hline St Pierre en Port S & 2 & Lewes et Seaford & N50 & 43 & 29 \\
\hline Eletot & 2 & Lewes et Seaford & $\mathrm{N} 60$ & 83 & 62 \\
\hline Senneville N & 3 & $\begin{array}{c}\text { New Pit, Lewes et } \\
\text { Seaford }\end{array}$ & N60 & 32 & 0 \\
\hline Fécamp N & 4 & $\begin{array}{c}\text { Zig Zag, Holywell, New } \\
\text { Pit, Lewes }\end{array}$ & N50 & 48 & 0 \\
\hline Yport N & 2 & Lewes et Seaford & N65 & 12 & 0 \\
\hline Yport S & 2 & Lewes et Seaford & N90 & 31 & 12 \\
\hline Le Tilleul N & 3 & New Pit, Lewes, Seaford & N35 & 159 & 0 \\
\hline Le Tilleul S & 2 & Holywell, New Pit & $\mathrm{N} 40$ & 24 & 35 \\
\hline
\end{tabular}

Table 1 : Characteristics of the sites investigated for fracture evaluation 


\begin{tabular}{|c|c|c|c|c|c|c|c|c|c|c|c|}
\hline Site & $\begin{array}{c}\text { F1 Main } \\
\text { fracture set on } \\
\text { the cliff }\end{array}$ & \begin{tabular}{|c|} 
F2 Main \\
fracture set on \\
the cliff
\end{tabular} & $\begin{array}{c}\text { S1 Minor } \\
\text { fracture set on } \\
\text { the cliff }\end{array}$ & $\begin{array}{c}\text { S2 Minor } \\
\text { fracture set on } \\
\text { the cliff }\end{array}$ & \begin{tabular}{|c|} 
S3 Minor \\
fracture set on \\
the cliff
\end{tabular} & $\begin{array}{c}\text { Dominating } \\
\text { cliff fracture } \\
\text { typology }\end{array}$ & $\begin{array}{c}\text { Beach fracture } \\
\text { typology }\end{array}$ & $\begin{array}{l}\text { Main fracture } \\
\text { set on the } \\
\text { beach }\end{array}$ & $\begin{array}{c}\text { S1 Minor } \\
\text { fracture set on } \\
\text { the beach }\end{array}$ & $\begin{array}{c}\text { S2 Minor } \\
\text { fracture set on } \\
\text { the beach }\end{array}$ & $\begin{array}{c}\text { S3 Minor } \\
\text { fracture set on } \\
\text { the beach }\end{array}$ \\
\hline Ault Nord & N120 & & N25 & N105 & N160 & Fractures & & & & & \\
\hline Ault S & N140 & N110 & & & & & & & & & \\
\hline Bois de Cise $\mathrm{N}$ & N130 & & N110 & N020 & N155 & Fractures & & N120 & N055 & & \\
\hline Mers les Bains $\mathrm{N}$ & N110 & N90 & & & & Normal faults & & & & & \\
\hline Criel sur Mer $\mathrm{N}$ & N000 & & & & & Fractures & & & & & \\
\hline Criel sur Mer S & N140 & N120 & N155 & N105 & & Master joints & & & & & \\
\hline Val Pollet & N135 & & & & & Master joints & & & & & \\
\hline Penly N & N090 & & N015 & N070 & & Normal faults & & N080 & N040 & N060 & \\
\hline St Martin N & N120 & & N010 & N070 & & Master joints & Joints & & & & \\
\hline Puys $\mathrm{N}$ & N110 & & N050 & & & Master joints & Normal faults & & & & \\
\hline Puys S & N110 & & & & & Master joints & Normal faults & & & & \\
\hline Dieppe S & N115 & & & & & Joints & Master joints & & & & \\
\hline Pourville S & N130 & & & & & Master joints & & & & & \\
\hline Quiberville N & N110 & & N095 & N145 & & Master joints & Normal faults & & & & \\
\hline St Aubin sur Mer $\mathrm{N}$ & N125 & N140 & N160 & & & Normal faults & & & & & \\
\hline Epineville & N125 & & & & & Normal faults & & & & & \\
\hline Sotteville La Pointue & N120 & & & & & Normal faults & Master joints & & & & \\
\hline Veules les Roses N & N130 & & & & & Normal faults & & & & & \\
\hline Veules les Roses S & N140 & & & & & Normal faults & & & & & \\
\hline St Valéry en Caux N & N115 & N90/ N165 & & & & Master joints & Normal faults & $\mathrm{N} 130$ & & & \\
\hline Veulettes sur Mer $\mathrm{N}$ & N135 & & & & & Joints & & & & & \\
\hline Veulettes sur Mer S & N110 & & & & & Joints & Master joints & N120 & & & \\
\hline St Martin aux Buneaux & N130 & & & & & Master joints & Joints & & & & \\
\hline Les Petites Dalles N & N120 & & & & & Master joints & Joints & N120 & N35 & N160 & N100 \\
\hline Les Grandes Dalles S & & & & & & & & N60 & & & \\
\hline St Pierre en Port N & N110 & N10 & & & & Master joints & Joints & N110 & N10 & N25 & N165 \\
\hline St Pierre en Port S & N105 & & N170 & & & Master joints & Joints & $\mathrm{N} 60$ & & & \\
\hline Eletot & N145 & & N30 & & & Normal faults & & N160 & N100 & & \\
\hline Senneville N & N140 & N150 & N165 & & & Normal faults & & & & & \\
\hline Fécamp N & N120 & NOOO & & & & Master joints & & & & & \\
\hline Yport N & N110 & & & & & Master joints & & & & & \\
\hline Yport S & N115 & & & & & Joints & Master joints & N150 & N100 & & \\
\hline Le Tilleul $\mathrm{N}$ & N115 & & N15 & N165 & & Fractures & & & & & \\
\hline Le Tilleul S & N120 & & & & & Joints & Synsediment. & $\mathrm{N} 40$ & N120 & N15 & N165 \\
\hline
\end{tabular}

Table 2 : Fracture dataset characteristics collected on the cliff and on the beach platform 